\title{
Development of Optical-based and Imaging Technology Detection, Diagnosis and Prevention of Aflatoxin Contamination on Maize Crop
}

\author{
Ghaniya Rashid ${ }^{1}$, Kisangiri Michael ${ }^{2}$, and Ernest Mbega ${ }^{3}$ \\ Research Scholar ${ }^{1}$, Senior Lecturer ${ }^{2-3}$ \\ ${ }^{1-2}$ School of Computational Communications Science and Engineering, \\ ${ }^{3}$ School of Life Science and Bioengineering, \\ Nelson Mandela African Institution of Science and Technology,
}

Arusha, Tanzania

\begin{abstract}
Aflatoxins are mycotoxins produced naturally by some mold strains, such as Aspergillus flavus and Aspergillus parasiticus. Weather factors, notably moisture levels of more than 18 percent and temperatures of more than $32^{\circ} \mathrm{C}$, influence the proliferation of aflatoxin-producing fungus. Aflatoxin pollution is a danger to human and animal healthiness. As a result, there is a pressing need to control aflatoxin, particularly in crops like maize, in countries where aflatoxin susceptibility is high, such as Tanzania. Several aflatoxin management solutions are being developed, however, for them to be effective, accurate identification of fungus or aflatoxins contamination on grain surfaces is required. While the majority of the known solutions include growing and identifying the fungus responsible or using Higher-Performance Liquid Chromatography (HPCL), Thin Layer Chromatography (TLC), and Enzyme-Linked Immunosorbent Assays (ELISA) to detect aflatoxin early, this review underlines the prospect of employing computer-based techniques to detect aflatoxin early. Because of these options, producers will be able to quickly detect aflatoxin contamination and, as a result, make informed decisions about how to prevent and/or reduce aflatoxin contamination, hence enhancing maize quality and storability.
\end{abstract}

Key Words: Aflatoxin-contamination, aflatoxin-management, temperature, humidity, optical-based, pre/ post-harvesting.

\section{INTRODUCTION}

Aflatoxins are mycotoxins produced naturally by mold strains such as Aspergillus flavus and Aspergillus parasiticus [1, 2]. Cereals (maize, sorghum wheat, and beans), nutty (peanuts, cashew nuts), cotton, and fruits are among the crops they attack [3]. Because maize (Zea mays L.) is Tanzania's principal food crop, it has been used as a model crop in this research. A key food crop is consumed by more than $75 \%$ of the country's population [4]. It is also known to be a critical food security crop and a source of income for more than half of the country's population who live in rural areas.

Due to the influence of climatic factors such as (increased temperature and high precipitation) and biological factors such as insects and fungal contaminations, aflatoxin contamination commonly develops in maize during storage or/and processing. [3] as previously pointed out aflatoxin levels should not exceed $20 \mu \mathrm{g} / \mathrm{kg}$ for human beings and $100 \mu \mathrm{g} / \mathrm{kg}$ for animals [4]. Aflatoxin exposure is primarily obtained from the consumption of contaminated food, which is hazardous to both human's and animals' health. The chemicals can have severe and long-term harmful effects, posing substantial health risks to humans and animals. They can cause hepatotoxicity, teratogenicity, and immunotoxicity, among other things. [5,6].

Efforts to correctly identify infected grains to prevent harmful effects on humans have been initiated by some scholars [7]. In their study, they attempted to separate contaminated maize grains based on color and texture by sorting the grains with some fungal- 
infected color. Other methods such as involving culturing of the fungus have been developed but they involve the destruction of grains for resolution and take a long time (up to 7 days) before the fungi are identified.

Furthermore, Higher-Performance Liquid Chromatography (HPCL), Thin Layer Chromatography (TLC), and Enzyme-Linked Immunosorbent Assays(ELISA) are the official standard methods readily presented for aflatoxin recognition and/or quantification [8]. All of these methods demand the use of specialized equipment as well as a lengthy extraction process. These methods are timeconsuming, necessitate destructive sampling, and require expert personnel despite their high accuracy, sensitivity, and dependability. These drawbacks make it difficult to utilize regularly. [9].

As a result, numerous non-destructive approaches are blossoming in the agricultural area to interchange the traditional ways to overcome these issues. Hyperspectral imaging (HSI) is a promising technology for assessing the quality of a variety of agro-food items. It is a fast plus non-destructive technique for spotting aflatoxin in cereals, such as optical-based, which may be suited for real-time detection and fewer sample preparations $[10,11]$. The main goal of this review was to create a baseline from the literature on the applicability of optical-based technology for improved detection and prevention of aflatoxin contamination and its effects on consumers. As a result, integrated methods and optical-based application in the maize price chains are being used to prevent aflatoxin contamination and reduce aflatoxin presence in the foodstuff system, with the overall impact of refining food safety and food safekeeping, which will eventually improve public health, nutrition, agricultural yield, and trade.

\section{RELATED WORKS}

\subsection{Mechanism of the aflatoxin contamination in maize}

Infection of maize is highly associated with pre and post-harvesting and poor storage practices [12]). About $95 \%$ of the farmers store their grains in-house using insect susceptible methods such as sacks which, also have been cited to be the main cause of aflatoxin-contamination [13]. The maize is contaminated during pre-harvest and under favorable conditions such as higher temperature, higher precipitation and moisture, and improper storage of food. Fungi, pests, and aflatoxins might be severe when conditions are disposed of, issues in grain storage systems. Aspergillus species present in decaying plants, the soil, and their spores are transferred via air streams and insects to crops and food rooms [14].

The increase in climate change effects is likely to increase the risk of aflatoxin-contamination in staple food example maize and as it is known that climate change influences pests and disease development [3]. Therefore when the weather conditions change and become warmer or precipitous while the maize is not well dried, stored, or packed the molds grown on the maize by spoil kernel and furthered more to the whole structure by contaminating part by part [15-17].

Developing innovative, optical-based methods is significant for aflatoxin management and prevention as food insecurity not only affects human health and its risk at large but also affects the social and economic aspects [18]. Optical-based techniques have been said to offer a lot of potential for online output since they have good outcomes for detecting aflatoxin and fungal contamination in future technologies. Thus, there is a necessity to derive innovative optical-based methods.

\subsection{Aflatoxin detection methods}

There are varieties of optical-based detection technologies that have been developed by various academics. [7, 19] see Table 1 . 
Table 1: Detection methods

\begin{tabular}{|c|c|c|c|c|}
\hline $\begin{array}{l}\text { Methods (purpose } \\
\text { of study) }\end{array}$ & Working principle & Advantages & Challenges & References \\
\hline $\begin{array}{l}\text { 1. One- and two- } \\
\text { photon induced } \\
\text { fluorescence } \\
\text { spectroscopy were } \\
\text { used to identify } \\
\text { aflatoxins in maize. }\end{array}$ & $\begin{array}{l}\text { Techniques for detecting } \\
\text { aflatoxins via optical } \\
\text { spectroscopic detection It } \\
\text { can also assess the water } \\
\text { content of items, detect color } \\
\text { aberrations, and identify } \\
\text { foreign objects in food } \\
\text { streams using absorption and } \\
\text { fluorescence spectroscopy, } \\
\text { allowing them to be } \\
\text { recognized optically. }\end{array}$ & $\begin{array}{l}\text { The intrinsic } \\
\text { fluorescence signal in } \\
\text { both healthy and } \\
\text { infected maize grains is } \\
\text { diminished in time and } \\
\text { accuracy. }\end{array}$ & $\begin{array}{l}\text { Toxic pollutants in } \\
\text { food or feed } \\
\text { products are } \\
\text { difficult to detect } \\
\text { unless the } \\
\text { contamination } \\
\text { level is high and } \\
\text { the approach is } \\
\text { costly. }\end{array}$ & {$[20]$} \\
\hline $\begin{array}{l}\text { 2. Classification of } \\
\text { aflatoxin } \\
\text { Contaminated } \\
\text { Single Corn } \\
\text { Kernels by } \\
\text { Ultraviolet to Near- } \\
\text { Infrared } \\
\text { Spectroscopy } \\
\text { (NIR). }\end{array}$ & $\begin{array}{l}\text { Using the spectra and the } \\
\text { aflatoxin concentration, to } \\
\text { classify single corn kernels, } \\
\text { the machine classified } \\
\text { individual kernels to see the } \\
\text { level of contamination and } \\
\text { identification of aflatoxins in } \\
\text { corns. }\end{array}$ & $\begin{array}{l}\text { The models can } \\
\text { accurately estimate the } \\
\text { aflatoxin level of } \\
\text { kernels by } 95.3 \text { percent } \\
\text { and by every single } \\
\text { kernel observed. }\end{array}$ & $\begin{array}{l}\text { The spectroscopy } \\
\text { system classifies } \\
\text { single maize } \\
\text { kernels tainted } \\
\text { with aflatoxin } \\
\text { from } 304 \text { to } 1,086 \\
\text { nm, above or } \\
\text { below which it } \\
\text { cannot perceive. }\end{array}$ & {$[21]$} \\
\hline $\begin{array}{l}\text { 3. Advances in } \\
\text { nanomaterial- } \\
\text { mediated bio and } \\
\text { immunological } \\
\text { sensors for } \\
\text { aflatoxin detection } \\
\text { in food products } \\
\text { have recently been } \\
\text { made. }\end{array}$ & $\begin{array}{l}\text { In this study, the author uses } \\
\text { different optical biosensors } \\
\text { for the detection of aflatoxin } \\
\text { in pistachio kernels such as } \\
\text { Optical biosensors based on } \\
\text { evanescent waves Optical } \\
\text { biosensors that glow in the } \\
\text { dark Optical biosensors with } \\
\text { Chemiluminescence Optical } \\
\text { colorimetric biosensors }\end{array}$ & $\begin{array}{l}\text { The majority of studies } \\
\text { suggest that biosensors } \\
\text { proposed in the } \\
\text { literature for aflatoxin } \\
\text { testing have great } \\
\text { stability, precision, and } \\
\text { accuracy. }\end{array}$ & & {$[22]$} \\
\hline $\begin{array}{l}\text { 4. Application of } \\
\text { multiplexing fiber- } \\
\text { optic laser-induced } \\
\text { fluorescence } \\
\text { spectroscopy for } \\
\text { detection of } \\
\text { aflatoxin B1 } \\
\text { contaminated } \\
\text { pistachio nuts }\end{array}$ & $\begin{array}{l}\text { The multiplexed fiber-optic } \\
\text { laser-induced fluorescence } \\
\text { spectroscopy (LIFS) system } \\
\text { with one-, two-, and three- } \\
\text { probes were used to detect } \\
\text { intentionally aflatoxin }(5,10 \text {, } \\
20,30 \text {, and } 50 \text { particles per } \\
\text { billion (ppb) contaminated } \\
300 \text { pistachio kernels, } \\
\text { respectively. }\end{array}$ & $\begin{array}{l}\text { The machine had the } \\
\text { highest accuracy of } 97.0 \\
\text { percent while using the } \\
\text { spectral range of } 390- \\
660 \mathrm{~nm} \text {. }\end{array}$ & $\begin{array}{l}\text { Both the control } \\
\text { and contaminated } \\
\text { samples' spectral } \\
\text { curves had a } \\
\text { similar form and } \\
\text { were overlapped, } \\
\text { especially from } \\
\text { the low-intensity } \\
\text { samples. }\end{array}$ & [23] \\
\hline $\begin{array}{l}\text { 5. Near-infrared } \\
\text { hyperspectral } \\
\text { imaging for }\end{array}$ & $\begin{array}{l}\text { It detects the single } \\
\text { contaminated kernel by using } \\
\text { color texture when screened }\end{array}$ & $\begin{array}{l}\text { Every single kernel near } \\
\text { the machine was } \\
\text { detected thus the }\end{array}$ & $\begin{array}{l}\text { To eliminate the } \\
\text { miscalculation of } \\
\text { the residual }\end{array}$ & [24] \\
\hline
\end{tabular}




\begin{tabular}{|c|c|c|c|c|}
\hline $\begin{array}{l}\text { detecting Aflatoxin } \\
\text { B1 of maize grains. }\end{array}$ & $\begin{array}{l}\text { by light therefore fungus- } \\
\text { infected kernels would } \\
\text { disperse more light Green } \\
\text { and red were used to } \\
\text { represent healthy and } \\
\text { infected kernels, } \\
\text { respectively. }\end{array}$ & $\begin{array}{l}\text { machine was very } \\
\text { accurate by } 92.3 \% \text {. The } \\
\text { majority of the kernels, } \\
\text { on the other hand, were } \\
\text { mislabeled for aflatoxin } \\
\text { contamination, with } \\
\text { those that were clear } \\
\text { carrying nearly no or } \\
\text { barely more than } 20 \\
\text { ppb. }\end{array}$ & $\begin{array}{l}\text { kernel, which was } \\
\text { in the middle of } \\
\text { health and } \\
\text { contamination, } \\
\text { sample } \\
\text { preparation must } \\
\text { be improved. }\end{array}$ & \\
\hline $\begin{array}{l}\text { 6. Raman } \\
\text { Spectroscopy for } \\
\text { Aflatoxins in } \\
\text { Maize: Rapid } \\
\text { Detection. }\end{array}$ & $\begin{array}{l}\text { Surface-enhanced Raman } \\
\text { spectroscopy (SERS) was } \\
\text { used to categorize and } \\
\text { compute the level of } \\
\text { aflatoxin in maize at } \\
\text { concentrations of } 0 \text { to } 1,206 \\
\mu \mathrm{g} / \mathrm{kg} \text {. }\end{array}$ & $\begin{array}{l}\text { It has great possibilities } \\
\text { to detect aflatoxin in } \\
\text { maize compared to } \\
\text { Near-Infrared NIR } \\
\text { spectroscopy and has } \\
\text { higher sensitivity when } \\
\text { contaminated maize } \\
\text { passes mostly between } \\
\text { below and above } 20 \\
\mu \mathrm{g} / \mathrm{kg} \text { samples. }\end{array}$ & $\begin{array}{l}\text { According to the } \\
\text { study, } \\
\text { conventional } \\
\text { Raman spectra } \\
\text { generated from the } \\
\text { same samples } \\
\text { were significantly } \\
\text { weaker than SERS } \\
\text { spectra, and they } \\
\text { shifted in different } \\
\text { SERS spectral } \\
\text { areas. }\end{array}$ & {$[25]$} \\
\hline $\begin{array}{l}\text { 7. Aflatoxins and } \\
\text { fungal } \\
\text { contamination in } \\
\text { agricultural goods } \\
\text { have recently been } \\
\text { detected using } \\
\text { optical approaches } \\
\text { that are quick and } \\
\text { non-destructive. }\end{array}$ & $\begin{array}{l}\text { The author compared three } \\
\text { optical mechanisms for the } \\
\text { detection of aflatoxin in } \\
\text { maize, which is Near- } \\
\text { infrared spectroscopy, which } \\
\text { uses chemicals for the } \\
\text { testing. Fluorescence } \\
\text { spectroscopy was it worked } \\
\text { on the principle of light } \\
\text { emission to absorption of UV } \\
\text { light. With kernel with } \\
\text { aflatoxin will irradiate blue- } \\
\text { fluorescence light. Moreover, } \\
\text { hyperspectral imaging } \\
\text { incorporates spectroscopic } \\
\text { and imaging systems to } \\
\text { produce information. }\end{array}$ & $\begin{array}{l}\text { They are a promising } \\
\text { and helpful method for } \\
\text { detecting dangers and } \\
\text { chemical components. }\end{array}$ & $\begin{array}{l}\text { The approaches } \\
\text { are highly } \\
\text { complicated, and } \\
\text { they may collide } \\
\text { with analytical } \\
\text { data. }\end{array}$ & {$[11,26,27]$} \\
\hline $\begin{array}{l}\text { 8. Using short wave } \\
\text { infrared (SWIR) } \\
\text { hyperspectral } \\
\text { imaging, aflatoxin } \\
\text { B1 (AFB1) was } \\
\text { detected in } \\
\text { individual maize } \\
\text { kernels. }\end{array}$ & $\begin{array}{l}\text { The mechanism uses } \\
\text { characterized wavelength of } \\
(1000-2500) \mathrm{nm} \text { to detect the } \\
\text { infection grains and } \\
\text { differentiate the health one } \\
\text { by hyperspectral imaging. }\end{array}$ & $\begin{array}{l}\text { The imagery was } \\
\text { cleansed by } 95.45 \% \text {, } \\
\text { and the tainted kernels } \\
\text { were detected. It's a } \\
\text { quick and precise } \\
\text { mechanism. }\end{array}$ & $\begin{array}{l}\text { The process } \\
\text { detects a single } \\
\text { kernel thus needs } \\
\text { to be improved. }\end{array}$ & {$[9,10]$} \\
\hline $\begin{array}{l}\text { 9. A technique for } \\
\text { examining } \\
\text { aflatoxin B1 }\end{array}$ & $\begin{array}{l}\text { When the contaminated } \\
\text { illuminated blue fluorescence } \\
\text { and the normally illuminated }\end{array}$ & $\begin{array}{l}\text { The mechanism was } \\
\text { accurate and fast by } \\
96.9 \% \text { by both }\end{array}$ & $\begin{array}{l}\text { Challenge slight- } \\
\text { confusion was } \\
\text { observed with a }\end{array}$ & {$[8,11]$} \\
\hline
\end{tabular}


International Journal of Advances in Scientific Research and Engineering (ijasre), Vol 8 (2), February -2022

\begin{tabular}{|c|c|c|c|c|}
\hline $\begin{array}{l}\text { (AFB1) on corn } \\
\text { kernels using short } \\
\text { wave infrared } \\
\text { (SWIR) } \\
\text { hyperspectral } \\
\text { imaging }\end{array}$ & $\begin{array}{l}\text { red fluorescence were passed } \\
\text { under UV irradiation, both } \\
\text { infected and healthy kernels } \\
\text { were screened using SWIR } \\
\text { hyperspectral over the } \\
\text { spectral range of (1100- } \\
\text { 1700) nm. }\end{array}$ & $\begin{array}{l}\text { calibrated and validated } \\
\text { sets. }\end{array}$ & kernel of $10 \mu \mathrm{g} / \mathrm{kg}$. & \\
\hline $\begin{array}{l}\text { 10. Classification } \\
\text { of corn kernels } \\
\text { contaminated with } \\
\text { aflatoxins using } \\
\text { fluorescence and } \\
\text { reflectance } \\
\text { hyperspectral } \\
\text { images analysis }\end{array}$ & $\begin{array}{l}\text { The mechanism uses (VNIR) } \\
\text { under the characterized } \\
\text { wavelength of (700-800) nm } \\
\text { for screening both germ and } \\
\text { endosperm less and higher } \\
\text { than 20ppb using } \\
\text { fluorescence reflectance and } \\
\text { hyperspectral images. }\end{array}$ & $\begin{array}{l}\text { The highest overall } \\
\text { accuracy was } 92.67 \\
\text { percent for germs } \\
\text { greater than } 20 \mathrm{ppb} \text {, and } \\
86.67 \text { percent for } \\
\text { endosperms greater than } \\
\text { and less than 20ppb. }\end{array}$ & $\begin{array}{l}\text { For germ kernels } \\
\text { less than } 20 \mathrm{ppb} \text {, } \\
\text { the accuracy } \\
\text { percentage } \\
\text { performance was } \\
\text { low, implying that } \\
\text { the kernels should } \\
\text { be more } \\
\text { contaminated for } \\
\text { quick screening. }\end{array}$ & {$[26,28]$} \\
\hline $\begin{array}{l}\text { 11. Aflatoxin } \\
\text { detection at the } \\
\text { pixel level in maize } \\
\text { using feature } \\
\text { selection and } \\
\text { hyperspectral } \\
\text { imaging }\end{array}$ & $\begin{array}{l}\text { Using transmittance and } \\
\text { reflectance spectroscopy, } \\
\text { HIS discovered aflatoxin in } \\
\text { corn. To extract feature } \\
\text { bands, the author employs } \\
\text { three methods, one of which } \\
\text { involves selecting four } \\
\text { hyperspectral bands from } \\
\text { previous articles: } 390 \mathrm{~nm} \text {, } \\
440 \mathrm{~nm}, 540 \mathrm{~nm} \text {, and } 710 \\
\text { nm. Another way is to } \\
\text { compress the hyperspectral } \\
\text { volume by using feature } \\
\text { extraction PCA to acquire } \\
\text { the first } 5 \text { pcs, and the third } \\
\text { method is to use (Fscnca, } \\
\text { Fscmrmr, Relieff, and } \\
\text { Fishier algorithm) to choose } \\
\text { the top } 10 \text { feature bands to } \\
\text { display either clean or } \\
\text { contaminated. }\end{array}$ & $\begin{array}{l}\text { The approaches were } \\
\text { accurate to the tune of } \\
89.51 \text { percent, } 93.83 \\
\text { percent, and } 99.38 \\
\text { percent. } \\
\text { As a result, the third } \\
\text { method is the most } \\
\text { accurate of all. The } \\
\text { color red represented the } \\
\text { contaminated, while the } \\
\text { healthy kernels were } \\
\text { represented by the color } \\
\text { blue. }\end{array}$ & $\begin{array}{l}\text { It will take more } \\
\text { time to determine } \\
\text { if a pixel is } \\
\text { aflatoxin- } \\
\text { contaminated or } \\
\text { not. }\end{array}$ & {$[29,30]$} \\
\hline
\end{tabular}




\section{FRAMEWORK OF OPTIC SENSOR AND COMPUTER TECHNOLOGY}

This part describes the working principles of optical sensors and the imaging in aflatoxin detection.

\subsection{How the optical-based technology can be used for early diagnosis, Aflatoxin management, and prevention.}

The current state of development of quick and non-destructive optical-based detection technologies for aflatoxin detection in foods, such as LIFS, SWIR, NIR, and HIS imaging, has also been discussed. [27, 31], see Figures 1 and 2 below.

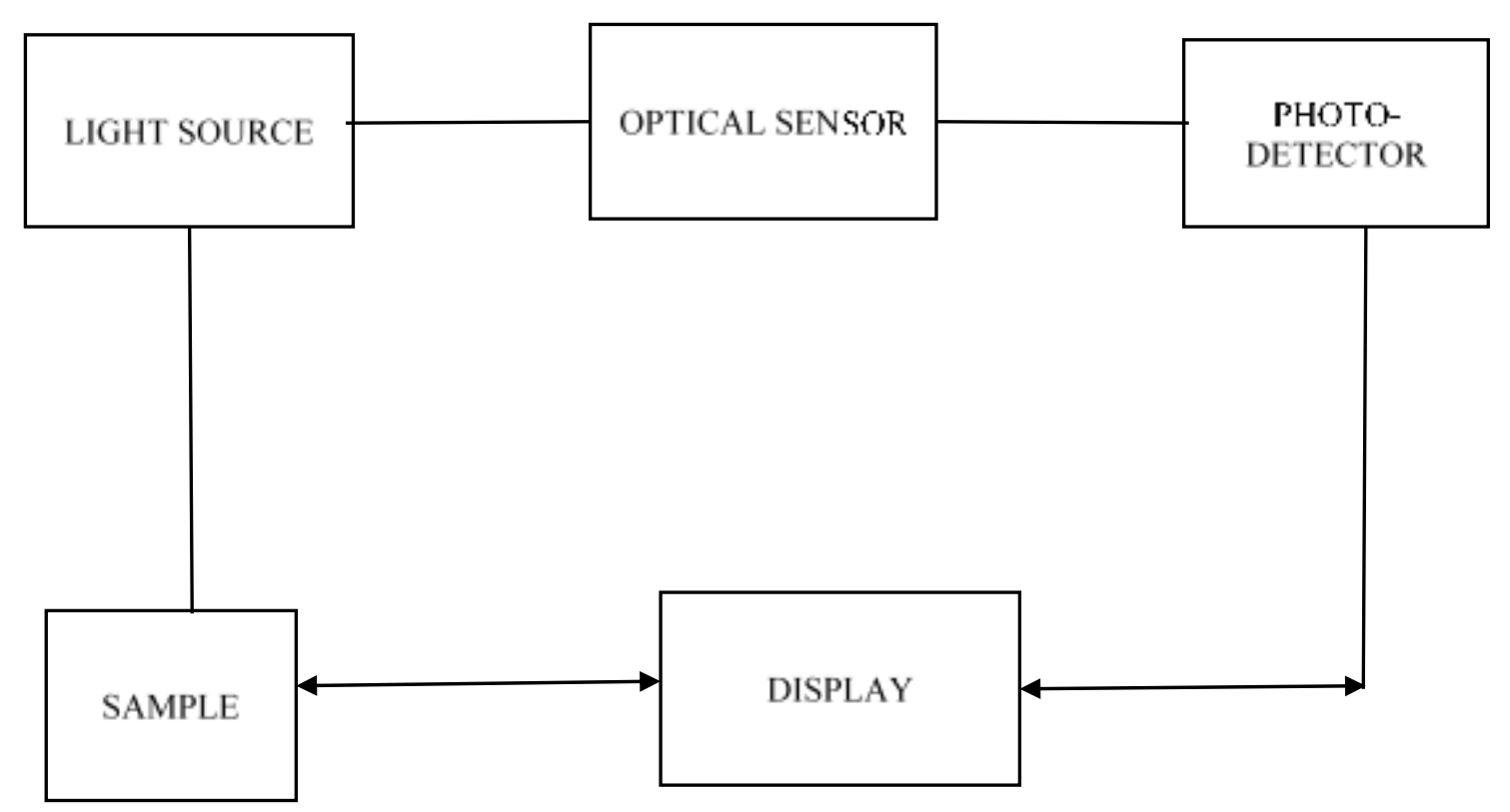

Figure 1: Conceptual framework by using fiber optical-sensor

The figure above has four parts the Light source can be [Emitting Diodes (LED) or Laser Diodes (LD's)] sensing part and photodetector. Optical sensors are sensors that respond optically to the concentration of analyses in a model. , and they can categorize in the function of the optical property that has been measured: absorbance, reflectance, fluorescence, phosphorescence, luminescence, Raman dispersion, evanescence, refraction index [32].

LED is a semiconductor light source that generates light when current flows through it, and a photodetector is an electronic device that gives an electrical signal based on received light signals $[33,34]$

A light source is required to electrify the fiber system, which includes the optical sensor-and a photodetector is required to read the light released by the sensing region, which comprises data about the sample and detecting information [35]. Optical fibers monitor the light from the excitation source to the sensing zone and from the sensing zone to the optical detector thus, the optical sensor senses chemical, biological, and physical changes of a sample by interaction through light intensity. Finally, the intended information can be seen at the display screen in a mode of electronic signals [35]. 


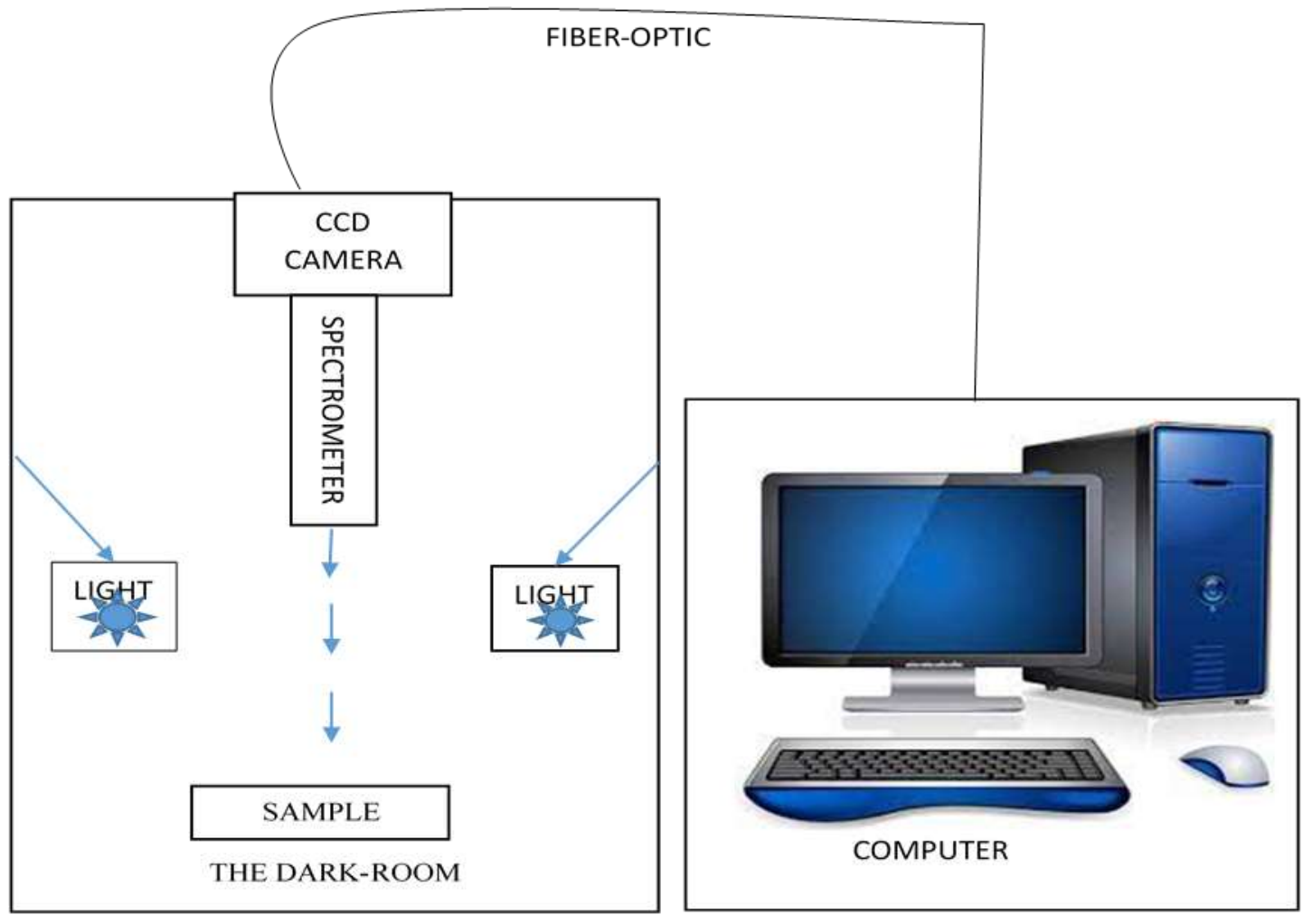

Figure.2. Conceptual framework by using a color imaging system

A color imaging system consists of a frame-grabber for picture acquisition, a sample holding stage, a Charge-Coupled Device (CCD) camera for image capture and conversion, a light source for accurate illumination, and a processer hardware and software for image processing [36]. The incident detectable band light falling on a partially reflecting surface of the sample produces a digital image [37]. The photons are collected in the camera lens, converted to electrical signals by a CCD, and then saved on a hard disk for image display and analysis [38].

\subsection{Applicability potential of optical-based technologies in Tanzania}

Recent studies demonstrate that using optical-based and hyperspectral-imaging technology for the accurate assessment of more food products has a bright future. Moreover, the analysis of using an optical-base system on the worth, safety investigation, and valuation grains, also, there are many other foodstuffs whose quality factors were effectively resolute based on these techniques in recent years such as meat, fish, fruits, and vegetables [39].

Optical-based aflatoxin management and prevention have several advantages over traditional mold management methods, including being less time-consuming, more accurate, more convenient, and more dependable. However, there are just a few strategies for determining the validity and reliability of computer-based prevention methods. In Tanzania, very adequate technologies for screening aflatoxins, such as optical-based and hyperspectral-imaging mechanisms, are still available on the market, as the systems are seen as essential in improving trade efficiency related to materials, modern agriculture, product processing, and management activities [40]. Experts predicted that its novel use of optical-based technologies would lower the threat of aflatoxin contamination in our harvests and increase yields. Finally, items will meet customer expectations and assist the food sector in better understanding and controlling the quality and safety of food.

\section{CONCLUSIONS}

Farmers' value preserving what has already been generated by employing HIS, computer control, smart agriculture, and internet of things applications throughout storage and pre-and post-harvesting, hence minimizing human workload. This study focuses on various scientific research findings on aflatoxin governor in nutrition and feedstuffs at the pre-and post-harvest levels, as well as optical-based processes. 
Aflatoxin contamination is common during pre-harvesting, post-harvesting, and storage, so following excellent agricultural practices, preventing fungal development in storage and the field, and maintaining proper temperature and relative humidity in silos and bags are all important. Improved bags, higher-quality herbicides and insecticides, and good maize harvesting and drying procedures will all result in high-quality crops with nil or low aflatoxin contamination. Our farmers and the people of Tanzania would benefit greatly from the use of computer-based and innovative technologies for aflatoxin screening. Not only the internet of things is used for real-time monitoring, observing, and sensing of parameter changes (temperature, precipitation, and humidity) in stores, but smart agricultural systems are also being used in maize farms.

Monitoring crops during storage by keeping optical sensors for moisture and temperature sensing is also important to reduce aflatoxin because water moisture and temperature are significant factors in fungal growth. Developing automatic control measures would improve storage stability in staple foods and real-time observing during pre and post-harvesting of cereals. If maize is not treated carefully during transportation and storage before reaching the final customers, it will be infected with aflatoxin.

As a result, leveraging and implementing the internet of things to track temperature and humidity in Lorries will be a huge success. Furthermore, knowledge of handling and control is still vital for aflatoxin food protection, and more procedures that are effective are needed to prevent contamination, as it is impossible to be aflatoxin-free, but we can handle to reduce aflatoxin levels during the storage and supply chain.

\section{CONFLICTS OF INTEREST}

On the submission of this work, the authors certify that they have no conflicts of interest.

\section{ACKNOWLEDGMENT}

I would like to send my appreciation and gratitude to my supervisors at my university.

\section{REFERENCES}

1. Sasamalo, M.M., J.K. Mugula, and C.J. Nyangi, Aflatoxins contamination of maize at harvest and during storage in Dodoma, Tanzania. International Journal of Innovative Research and Development, 2018. 7(6): p. 11-15.

2. Sardiñas, N., et al., Specific detection and quantification of Aspergillus flavus and Aspergillus parasiticus in wheat flour by SYBR® Green quantitative PCR. International journal of food microbiology, 2011. 145(1): p. 121-125.

3. Battilani, P., et al., Aflatoxin B 1 contamination in maize in Europe increases due to climate change. Scientific reports, 2016. 6(1): p. 1-7.

4. Sumner, P.E. and R.D. Lee Reducing aflatoxin in corn during harvest and storage. 2009.

5. Kumar, P., et al., Aflatoxins: a global concern for food safety, human health, and their management. Frontiers in microbiology, 2017. 7: p. 2170.

6. Kowalska, A., et al., Aflatoxins: characteristics and impact on human health. Postepy higieny i medycyny doswiadczalnej (Online), 2017. 71: p. 315-327.

7. Yao, H., Z. Hruska, and J.D. Di Mavungu, Developments in detection and determination of aflatoxins. World mycotoxin journal, 2015. 8(2): p. 181-191.

8. Kandpal, L.M., et al., Short wave infrared (SWIR) hyperspectral imaging technique for examination of aflatoxin B1 (AFB1) on corn kernels. Food Control, 2015. 51: p. 171-176.

9. Chu, X., et al., Detection of aflatoxin B1 (AFB1) in individual maize kernels using short wave infrared (SWIR) hyperspectral imaging. Biosystems Engineering, 2017. 157: p. 13-23.

10. Wang, W., et al., Identification of aflatoxin B1 on maize kernel surfaces using hyperspectral imaging. Food Control, 2014. 42: p. 78-86.

11.Tao, F., et al., Recent development of optical methods in rapid and non-destructive detection of aflatoxin and fungal contamination in agricultural products. TrAC Trends in Analytical Chemistry, 2018. 100: p. 65-81.

12. Chauhan, N.M., A.P. Washe, and T. Minota, Fungal infection and aflatoxin contamination in maize collected from Gedeo zone, Ethiopia. SpringerPlus, 2016. 5(1): p. 1-8. 
International Journal of Advances in Scientific Research and Engineering (ijasre), Vol 8 (2), February -2022

13. Shabani, I., et al., Maize storage and consumption practices of farmers in Handeni District, Tanzania: Corollaries for mycotoxin contamination. Open journal of preventive medicine, 2015. 5(08): p. 330.

14. Nesci, A., et al., Prevention of aflatoxin contamination in stored grains using chemical strategies. Current Opinion in Food Science, 2016. 11: p. 56-60.

15. Wu, F. and N. Mitchell, How climate change and regulations can affect the economics of mycotoxins. World Mycotoxin Journal, 2016. 9(5): p. 653-663.

16. Wu, F., et al., Climate change impacts on mycotoxin risks in US maize. World Mycotoxin Journal, 2011. 4(1): p. 79-93.

17. Warnatzsch, E.A., et al., Climate Change Impact on Aflatoxin Contamination Risk in Malawi's Maize Crops. Frontiers in Sustainable Food Systems, 2020. 4: p. 238.

18.Udomkun, P., et al., Innovative technologies to manage aflatoxins in foods and feeds and the profitability of application-A review. Food Control, 2017. 76: p. 127-138.

19. Gacem, M.A. and A.O. El Hadj-Khelil, Toxicology, biosynthesis, bio-control of aflatoxin and new methods of detection. Asian Pacific Journal of Tropical Biomedicine, 2016. 6(9): p. 808-814.

20. Smeesters, L., et al., Optical detection of aflatoxins in maize using one-and two-photon induced fluorescence spectroscopy. Food Control, 2015. 51: p. 408-416.

21. Cheng, X., A. Vella, and M.J. Stasiewicz, Classification of aflatoxin-contaminated single corn kernels by ultraviolet to nearinfrared spectroscopy. Food Control, 2019. 98: p. 253-261.

22.Eivazzadeh-Keihan, R., et al., Recent advances in nanomaterial-mediated bio and immune sensors for detection of aflatoxin in food products. TrAC Trends in Analytical Chemistry, 2017. 87: p. 112-128.

23. Wu, Q., and H. Xu, Application of multiplexing fiber-optic laser-induced fluorescence spectroscopy for detection of aflatoxin B1 contaminated pistachio kernels. Food chemistry, 2019. 290: p. 24-31.

24. Wang, W., et al., Near-infrared hyperspectral imaging for detecting Aflatoxin B1 of maize kernels. Food Control, 2015. 51: p. 347-355.

25.Lee, K.-M., et al., Feasibility of surface-enhanced Raman spectroscopy for rapid detection of aflatoxins in maize. Journal of agricultural and food chemistry, 2014. 62(19): p. 4466-4474.

26.Zhu, F., et al., Integration of fluorescence and reflectance visible near-infrared (VNIR) hyperspectral images for detection of aflatoxins in corn kernels. Transactions of the ASABE, 2016. 59(3): p. 785-794.

27.Xing, F., et al., Recent developments and applications of hyperspectral imaging for rapid detection of mycotoxins and mycotoxigenic fungi in food products. Critical reviews in food science and nutrition, 2019. 59(1): p. 173-180.

28.Zhu, F., et al. Classification of corn kernels contaminated with aflatoxins using fluorescence and reflectance hyperspectral images analysis. in Sensing for Agriculture and Food Quality and Safety VII. 2015. International Society for Optics and Photonics.

29. Gao, J., et al., Pixel-level aflatoxin detecting in maize-based on feature selection and hyperspectral imaging. Spectrochimica Acta Part A: Molecular and Biomolecular Spectroscopy, 2020. 234: p. 118269.

30.Han, Z. and J. Gao, Pixel-level aflatoxin detecting based on deep learning and hyperspectral imaging. Computers and Electronics in Agriculture, 2019. 164: p. 104888.

31. Agriopoulou, S., E. Stamatelopoulou, and T. Varzakas, Advances in analysis and detection of major mycotoxins in foods. Foods, 2020. 9(4): p. 518.

32.de Arruda Viana, L., et al., Optical sensors for precision agriculture: An outlook. Journal of Experimental Agriculture International, 2019: p. 1-9.

33. Wang, B., et al., Recent progress in high-performance photo-detectors enabled by the pulsed laser deposition technology. Journal of Materials Chemistry C, 2020. 8(15): p. 4988-5014.

34. Held, G., Introduction to light-emitting diode technology and applications. 2016: CRC Press. 
International Journal of Advances in Scientific Research and Engineering (ijasre), Vol 8 (2), February -2022

35.Pérez, M.A., O. González, and J.R. Arias, Optical fiber sensors for chemical and biological measurements. Current Developments in Optical Fiber Technology, 2013: p. $265 \mathrm{e} 291$.

36. Orina, I., M. Manley, and P.J. Williams, Non-destructive techniques for the detection of fungal infection in cereal grains. Food Research International, 2017. 100: p. 74-86.

37.Wu, D., and D.-W. Sun, Colour measurements by computer vision for food quality control-A review. Trends in Food Science \& Technology, 2013. 29(1): p. 5-20.

38. Vithu, P. and J. Moses, Machine vision system for food grain quality evaluation: A review. Trends in Food Science \& Technology, 2016. 56: p. 13-20.

39. Wu, D., and D.-W. Sun, Advanced applications of hyperspectral imaging technology for food quality and safety analysis and assessment: A review—Part II: Applications. Innovative Food Science \& Emerging Technologies, 2013. 19: p. 15-28.

40. Mwantimwa, K.J.J.o.G.E.R., ICT usage to enhance firms' business processes in Tanzania. 2019. 9(1): p. 1-23.

Correspondence Author : Ghaniya Hamad; hamadg@nm-aist.ac.tz 